\title{
PRINSIP SENI RUPA DALAM MENGGAMBAR ORNAMEN MELAYU
}

\author{
Us watun Has anah ${ }^{1 *}$, Fuad Erdansyah ${ }^{2 *}$ \\ Program Studi Pendidikan Seni Rupa Jurusan Seni Rupa Fakultas Bahasa dan Seni \\ Universitas Negeri Medan \\ Jl. Willem Iskandar Pasar V Medan Estate, Kec, Percut Sei Tuan, Kab. Deli Serdang, Kode Pos 20371 \\ Sumatera Utara. Indonesia \\ Email: uswatunhasanah97@gmail.com,ferdansyah@unimed.ac.id
}

\begin{abstract}
Abstrak
Penelitian ini bertujuan untuk mengetahui kemampuan siswa dalam menerapkan prinsip-prinsip seni rupa, yang meliputi prinsip kesatuan, keseimbangan, irama, proporsi, dan kontras, dalam menggambar ornamen Melayu dengan teknik patron atau mal oleh Siswa Kelas XI SMA Negeri 1 Talawi. Hasil penelitian ini menunjukan penerapan prinsip-prinsip seni rupa masih kurang benar dalam pembuatan ornamen melayu, keseimbangan yang terdapat dalam pembuatan ornamen belum menunjukan hasil yang maksimal, juga dalam prinsip proporsi belum menunjukan struktur bagian yang akurat antara bagian- bagian ornamen dan hasil teknik patron dalam pembuatan ornamen Melayu dengan menggunakan prinsip-prinsip seni rupa cenderung masih kurang rapi dan masih terlihat kasar dalam pewarnaan dan kerapian pada ornamen Melayu terlihat dari sisigaris tepi ornamen masih berantakan. Objek dari penelitian ini adalah hasil ornamen Melayu dengan menggunakan prinsip-prinsip seni rupa yang dihasilkan oleh siswa kelas XI SMA Negeri 1 Talawi. Hasil penelitian menjelaskan bahwa ornamen Melayu dengan teknik patron, yaitu dengan metode menggunakan cetakan, deng an memakai prinsip-prinsip seni rupa, dengan hasil tidak begitu baik.
\end{abstract}

Kata Kunci: prinsip, seni rupa, menggambar, ornamen.

\begin{abstract}
This research aims to know the ability of students to apply the principles offine arts, which include the principles of unity, balance, rhythm, proportion, and contrast, in drawing Malayornaments with patron or mall techniques by Grade XI Students of Sma Negeri 1 Talawi. The results of this study show the application of the principles offine art is still not correct in the manufacture of Malay ornaments, the balance contained in the making ofornaments has not shown maximum results, also in the principle of proportion has not shown the accurate structure of the parts between the ornaments and the results of patron techniques in the making of Malay ornamentsusing the principles offine art tend to still be less neat and still look rough in coloring and neatness on malay ornaments seen from the side of the outline ornaments are still messy. The object of this research is the result of Malay ornaments using the principles offine art produced by grade XI students of Sma Negeri 1 Talawi. The results explained that Malay ornaments with patron techniques, namely by using molds, using the principles offine art, with not so good results.
\end{abstract}

Keywords: principles, fine art, drawing ornaments.

\section{PENDAHULUAN}

Mata pelajaran Seni Budaya yang dilaksanakan di sekolah terdiri dari sub bidang seni rupa, seni musik, seni tari, dan seni teater. Setiap sekolah wajib melaks anakan minimal satu bidang seni yang tercakup dalam mata pelajaran Seni Budaya. Salah satu rumpun pembelajaran yang dilaksanakan di Sekolah Menengah Atas adalah Seni Budaya y ang mengkaji dan mencipta sebuah kary a seni dan kreatif yang berakar pada norma, nilai, perilaku, dan produk seni budaya bangsa. Kecakapan atau kemahiran dalam seni budaya diharapkan dapat tercapai melalui standar kompetensi berupa kemampuan memahami konsep seni rupa dan memahami pentingnya seni rupa dalam kehidupan. Dalam menggambar ornamen siswa juga harus memahami, prinsip-prinsip seni rupa dalam menggambar ornamen Melayu bertuju an sebagai cara mengatur, pengaturan unsur-unsur rupa sehingga membentuk suatu karya seni. Prinsip senirupa dapat juga disebut asas seni rupa, yang menekankan prinsip seni seperti: kesatuan, keseimbangan, irama, penekanan, proporsi dan keselarasan. Sebenarnya secara meteri tidak ada perubahan yang mendasar, karena semua prinsip tersebut masih seperti semula. Rendahnya kemampuan menggambar ornamen pada sis wa Kelas XI SMA Negeri 1 Talawi ini juga dilihat 


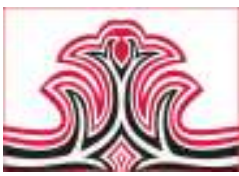

dari hasil KKM (Kemampuan, Ketrampilan, Minimum) yang diperoleh dari hasil laporan dalam menggambar. Oleh karena itu penelitian ini penting dilaksanakan untuk mengetahui sejauh mana kemampuan sis wa dalam menerapkan prinsip-prinsip seni rupa dalam menggambar ornamen sebagai dasar konsep menggambar ornamen Melayu dengan teknik Mal.

Berdasarkan latar belakang masalah dan identifikasi masalah, maka batas an masalah dalam penelitian ini adalah :Penerapan Prinsip-prinsip Seni pada hasil karya siswa dalam menggambar ornamen Melayu dengan teknik Patron/Mal di SMA Negeri 1 Talawi. Manfaat praktis dari penelitian ini antara lain adalah :Memberikan gambaran tentang ornamen Melayu yang memiliki unsur-unsur garis, warna, bentuk, tekstur, ruang atau gelap terang, dan organisasi dari unsur lukisan yang meliputi kesatuan, kesimbangan, irama dan perbandingan ukuran. Hasil yang diperoleh dan penelitian ini diharapkan dapat bermanfaat secara teoritis dan praktis.

Manfaat teoretis penelitian iniantara lain adalah untuk memperkaya dan menambah wawasan ilmu pengetahuan baik bersifat praktis maupun teoritis guna meningkatkan kualitas pembelajaran khususnya yang berkaitan dengan karya, prinsip-prinsip seni rupa, referensi bagi mahasiswa jurusan Seni Rupa FBS UNIMED, bahan masukan dan menambahan wawasan penulis dalam rangka penelitian mahasiswa, bahan pengetahuan sis wa membuat karya.

Manfaat praktis dari penelitian ini antara lain adalah : Memberikan gambaran tentang ornamen Melayu yang memiliki unsur-unsur garis, warna, bentuk, tekstur, ruang atau gelap terang, dan organisasi dari unsur lukisan yang meliputi kesatuan, kesimbangan, irama dan perbandingan ukuran.

\section{KAJIAN TEORI}

\section{Prinsip Seni Rupa}

"Prinsip-prinsip seni rupa adalah cara penyusunan, pengaturan unsur-unsur rupa sehingga membentuk suatu karya seni. Prinsip Seni Rupa dapat jug a disebut asas seni rupa, yang menekankan prinsip desain seperti: kesatuan, keseimbangan, irama, penekanan, proporsi dan kontras. Desain atau yang dulu diis tilahkan dengan sebutan nirmana sebenarnya secara meteri tidak ada perubahan yang mendasar, karena semua prinsip tersebut masih seperti semula." (Sahman, 1993). Selanjutnya Mesra dalam Siregar (2020: 96) mengungkapkan tentang prinsip yang lebih ditekankan komposisi dalam menggambar merupakan suatu
Gorga : Jurnal Seni Rupa

Volume 09 Nomor 02 Juli-Desember 2020

p-ISSN: 2301-5942 | e-ISSN: 2580-2380

susunan dari beberapa unsur secara seimbang dan serasi atau harmonis, komposisi tersebut terdiri dari beberapa indikator yaitu: kesatuan, keseimbangan, irama, proporsi, keselarasan, dan penekanan.

Prinsip Kesatuan menunjukkan keadaan dimana berbagai unsur bentuk bekerja sama dalam menciptakan kesan keteraturan dan memberikan keseimbangan yang selaras antara bagian-bagian dan keseluruhan. Prinsip Keseimbangan adalah hubungan antara kekuatan-kekuatan yang bertentangan. Secara umum dikenal simetris dan asimetris. Pada karya tiga dimensi prinsip keseimbangan berkaitan dengan bobot aktual (Sembiring, 2013).

Prinsip Irama dalam karya seni dapat timbul jika ada pengulangan yang teratur dari unsur yang digunakan. Irama dapat terjadi pada karya seni rupa dari adanya pengaturan unsur garis, raut, warna, teksture, gelapterang secara berulang-ulang. Pengulangan unsur bisa bergantian yang biasa disebut irama alternatif. Irama dengan perubahan ukuran (besar-kecil) disebut irama progresif. Prinsip Proporsi adalah hubungan ukuran antar bagian dalamsuatu kes eluruhan. Sebagai contoh, perbandingan ukuran pada tubuh manusia, yang menghubungkan kepala dengan tinggi badan, lebar pundak dan panjang torso. Proporsi digunakan untuk menciptakan menciptakan keteraturan dan sering ditetapkan untuk membentuk standar keindahan dan kesempurnaan, misalnya proporsi manusia pada zaman Yunani klasik dan kemudian pada masa Renaisans.

Prinsip Kontras Menurut Sembiring (2013) dalam bukunya yang berjudul Wawasan Seni, mengatakan bahwa "Kontras adalah interaksi dari elemen- elemen yang mengekspresikan pertentangan antara keduan, misalnya kontras antara yang kecil dan yang besar, yang kasar dengan yang halus, yang statis dan yang dinamis".

\section{Menggambar Ornamen}

Gambar merupakan bahasa yang universal dan telah berkembang sebelum ditemukannya bahasa tulis an.Sejak zaman prasejarah manusia primitif telah mengenal gambar sebagai bahasa rupa.Hal ini dibuktikan dengan banyak ditemukannya gambar dan lukis an digoa-goa tempat manusia tinggal saat itu. Dari gambar-gambar tersebut terdapat beberapa kes amaan tema dan objek gambar.Pada umumnya, tema yang diangkat adalaah seputar kehidupan manusia seperti berburu binatang, benda-benda langit, dan ritual keagamaan yang berkembang saat itu. Ornamen juga berarti dekorasi atau hiasan sehingga ornament sering disebut sebagai desain dekoratif atau desain ragamhias. 


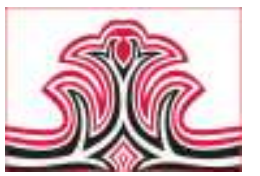

Menurut Moussavi (2010) Ornament is the figure that emerges from the material substrate, the expression of embedded forces through processes of construction, assembly and growth.Ornamen adalah sosok yang muncul dari substrat material, ekspresi gaya yang tertanam melalui proses konstruksi, perakitan dan pertumbuhan.

Dengan demikian dapat disimpulkan bahwa ornamen adalah upaya menambah keindahan dari hasil karya seni. Ornamen hadir di tengah-tengah masyarakat merupakan media sebagai ungkapan perasaan yang diwujudkan dalam bentuk visual dan berperan dalam pengembangan kebudayaan.Jadi kesimpulannyaadalah bahwa "ornamen adalah komponen produk Seni yang ditambahkan atau sengaja dibuat untuk tujuan sebagai hiasan.

\section{Teknik Patron atau Mal}

Dalam menggambar ragam hias, patron atau mal s ering digunakan untuk menggambar motif ragam hias yang berulang-ulang dan memiliki ukuran yang cendenung sama. Hal ini dimaksudkan untuk menghindari kesalahan dalam menggambar motif ragam hias sehing ga dapat men ghasilkan gambar yang seimbang dan rapi (Pratiwi, 2001).

Teknik mal adalah teknik untuk mempercepat proses penggambaran dengan menggunakan alat bantu.macam-macam jenis alat bantu Fungsi mal sebagai alat bantu untuk menggambar atau untuk mempercepat proses penggambaran berbagai macam bentuk.

\section{METODE PENELITIAN}

Adapun penelitian ini imeng gunakan metode deskriptif kualitatif dengan mengetahui bagaimana hasil karya ragam hias ornamen Melayu pada siswa, dan mendeskripsikan gambaran yang diteliti dan dinilai berdas arkan prinsip-prinsip seni rupa. Adapun sampel yang digunakan dalam penelitian ini adalah 20 karya siswa diambil secara terpilih lebih tepatnya menggunakan purposive sampling. Instrumen penelitian yang digunakal adalah observasi, dokumentasi, dan wawancara.

\section{HASIL DAN PEMBAHASAN \\ 1.Hasil}

Dari data yang terkumpul maka akan dibahas dalam pembahasan ini akan mendapatkan gambaran yang jelas akan prinsip seni rupa dalam menggambar ornamen Melayu dengan teknik Mal. Penilaian setiap karya dinilai berdasarkan angka-angka pada setiap indikator yang menjadi nilai pada setiap deskriptomya,
Gorga : Jurnal Seni Rupa

Volume 09 Nomor 02 Juli-Desember 2020 p-ISSN: 2301-5942 | e-ISSN: 2580-2380

adapun penilaian karya akan dibahas melaui rumusanrumusan mas alah yang sudah dipaparkan sebelumnya. Berikut adalah hasil penilaian terhadap karya dari masing-masing siswa untuk hasil kary a dengan prinsipprinsip seni rupa yang menjadi landasan hasil penciptaan karya siswa.

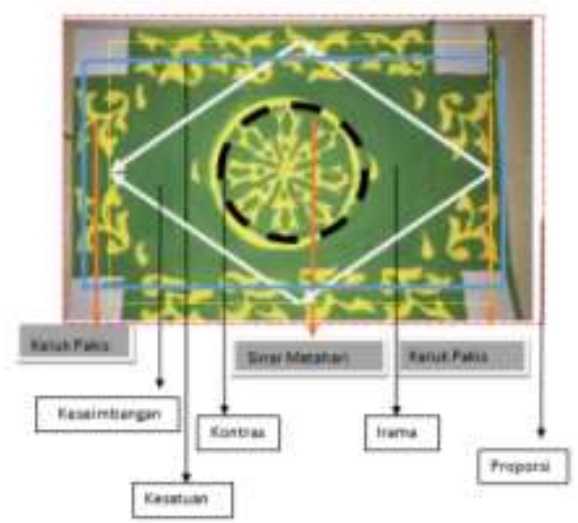

Gambar 1. Ornamen Melayu dengan Teknik Mal Bentuk Dasar Belah Ketupat (Hasanah, 2020)

Dalam hasil penelitian, karya ters ebut menghasilkan beberapa motif yaitu, keluk pakis ada 2 motif, dan sinar matahari ada 1 motif. Dan dalam karya tersebut menggunakan dua warna warna kuning dan warna hijau.Warna hijau diterapkan sebagai das ar atau latar belakang sedangkan warna kuning diterapkan pada bagian motif. Hasil dari pembuatan ornamen oleh siswa terlihat masih ada kelemahan yaitu bentuk ornamen keluk pakis belum menunjukan kerapian serta masih terlihat berantakan dan ornamen sinar matahari juga belummenunjukan kerapian pada sisi lingkaran, wama pada keseluruhan ornamen juga belum rapi, cat yang terdapat masih tebal tipis, belummenunjukan kerapian pada warna.

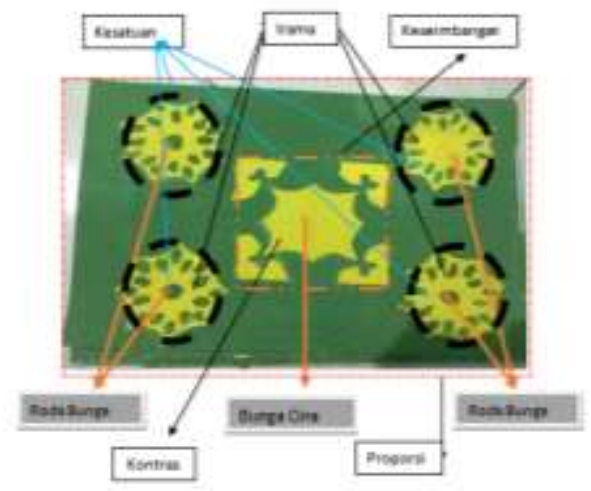

Gambar 2. Ornamen Melayu dengan Teknik Mal Empat Motif pada Empat Sisi (Hasanah, 2020)

Dalam hasil penelitian, karya ters ebut menghasilkan beberapa motif yaitu, roda bunga ada 2 motif, dan 


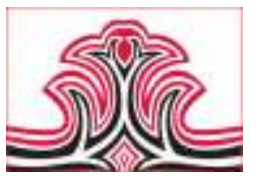

bunga cina ada 1 motif. Dan dalam karya tersebut menggunakan dua warna warna kuning dan warna hijau.Warna hijau diterapkan sebagai das ar atau latar belakang sedangkan warna kuning diterapkan dibagian pada motif. Hasil dari pembuatan ornamen oleh siswa terlihat maasih ada kelemahan yaitu bentuk ornamen roda bunga belum menunjukan kerapian serta masih terlihat berantakan dan ornamen bunga cina belum menunjukan kerapian pada sisi tengah, belum sesuai kerapian proporsi pada ornamen tersebut warna juga belum menunjukan keseluruhan bagian ornamen, cat yang terdapat masih jug a tebal tipis, belummenunjukan keserasian pada bidang.

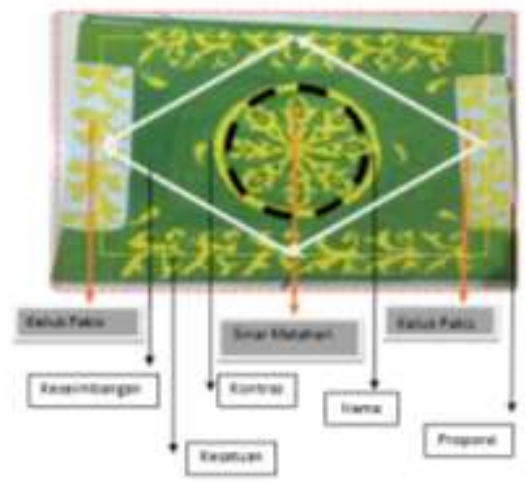

Gambar 3. Ornamen Melayu dengan Teknik Mal Satu Bentuk Lingkaran dan Satu Bentuk Belah Ketupat (Hasanah, 2020)

Dalam hasil penelitian, karya tersebut menghasilkan beberapa motif y aitu, keluk pakis ada 2 motif, dan sinar matahari ada 1 motif. Dan dalam karya tersebut menggunakan dua warna warna kuning dan warna hijau.Warna hijau diterapkan sebagai dasar atau latar belakang sedangkan warna kuning diterapkan dibagian pada motif. Hasil dari pembuatan ornamen oleh siswa terlihat maasih ada kelemahan yaitu bentuk ornamen keluk pakis belum menunjukan kerapian serta masih terlihat berantakan dan ornamen sinar matahari juga belummenunjukan kerapian pada sisi lingkaran, wama pada keseluruhan ornamen juga belum rapi, cat yang terdapat masih tebal tipis, belummenunjukan kerapian pada warna.
Gorga : Jurnal Seni Rupa

Volume 09 Nomor 02 Juli-Desember 2020 p-ISSN: 2301-5942 | e-ISSN: 2580-2380

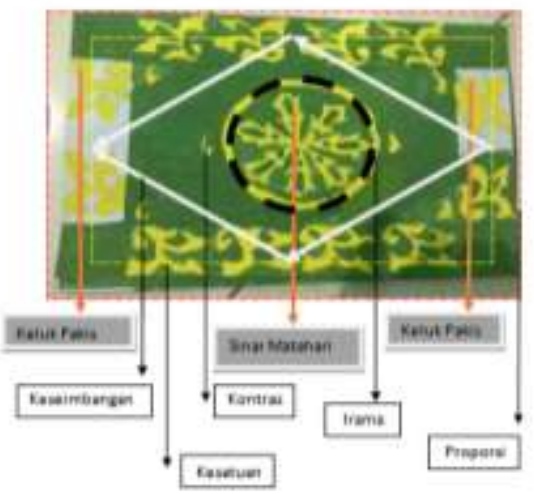

Gambar 4. Ornamen Melayu dengan Teknik Mal Satu Bentuk Lingkaran dan Satu Bentuk Belah Ketupat (Hasanah, 2020)

Dalam hasil penelitian, karya ters ebut menghasilkan beberapa motif yaitu, keluk pakis ada 2 motif, dan sinar matahari ada 1 motif. Dan dalam karya tersebut menggunakan dua warna warna kuning dan warna hijau.Warna hijau diterapkan sebagai dasar atau latar belakang sedangkan warna kuning diterapkan dibagian pada motif. Hasil dari pembuatan ornamen oleh siswa terlihat maasih ada kelemahan yaitu bentuk ornamen keluk pakis belum menunjukan kerapian serta masih terlihat berantakan dan ornamen sinar matahari juga belum menunjukan kerapian pada sisi lingkaran, wama pada keseluruhan ornamen juga belum rapi, cat yang terdapat masih tebal tipis, belummenunjukan kerapian pada warna.

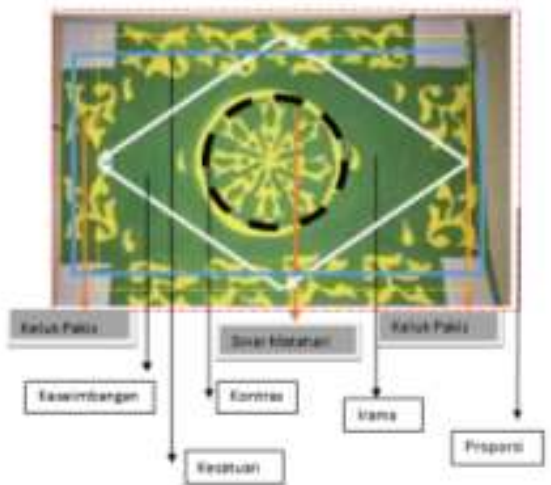

Gambar 5. Ornamen Melayu dengan Teknik Mal Satu Bentuk Lingkaran dan Satu Bentuk Belah Ketupat (Hasanah, 2020)

Dalam hasil penelitian, karya ters ebut menghasilkan beberapa motif yaitu, keluk pakis ada 2 motif, dan sinar matahari ada 1 motif. Dan dalam karya tersebut menggunakan dua warna warna kuning dan warna hijau.Warna hijau diterapkan sebagai dasar atau latar belakang sedangkan warna kuning diterapkan dibagian pada motif. Hasil dari pembuatan ornamen oleh siswa terlihat maasih ada kelemahan yaitu bentuk ornamen keluk pakis belum menunjukan kerapian serta masih 


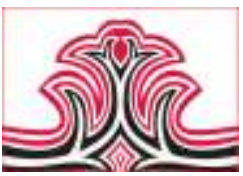

terlihat berantakan dan ornamen sinar matahari juga belummenunjukan kerapian pada sisi lingkaran, wama pada keseluruhan ornamen juga belum rapi, cat yang terdapat mas ih tebal tipis, belummenunjukan kerapian pada warna.

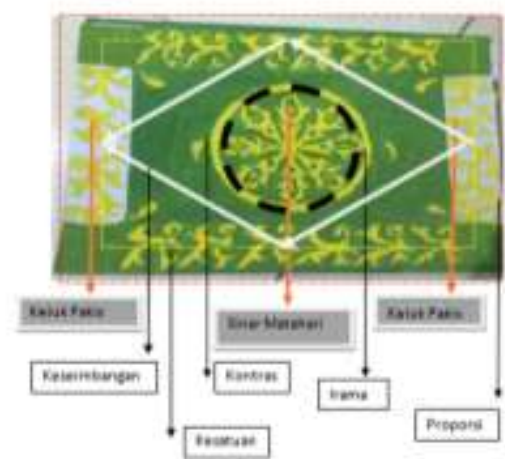

Gambar 6. Ornamen Melayu dengan Teknik Mal Satu Bentuk Lingkaran dan Satu Bentuk Belah Ketupat (Hasanah, 2020)

Dalam hasil penelitian, karya tersebut menghasilkan beberapa motif yaitu, keluk pakis ada 2 motif, dan sinar matahari ada 1 motif. Dan dalam karya tersebut menggunakan dua warna warna kuning dan warna hijau.Warna hijau diterapkan sebagai das ar atau latar belakang sedangkan warna kuning diterapkan dibagian pada motif. Hasil dari pembuatan ornamen oleh siswa terlihat maasih ada kelemahan yaitu bentuk ornamen keluk pakis belum menunjukan kerapian serta masih terlihat berantakan dan ornamen sinar matahari juga belummenunjukan kerapian pada sisi lingkaran, wama pada keseluruhan ornamen juga belum rapi, cat yang terdapat mas ih tebal tipis, belummenunjukan kerapian pada warna.

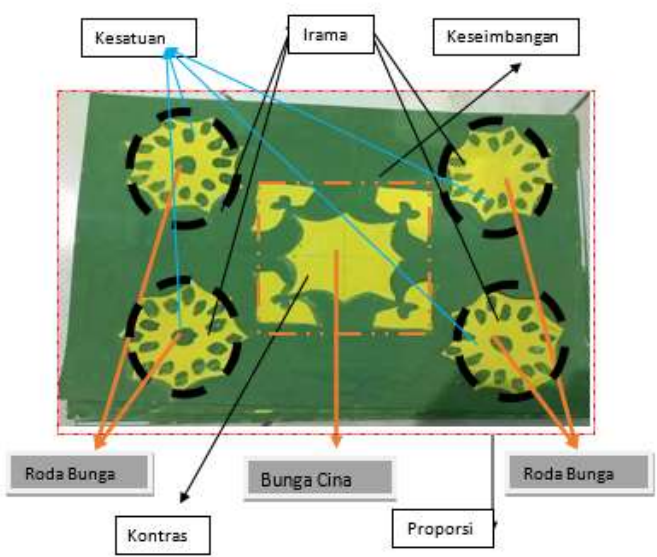

Gambar 7. Ornamen Melayu dengan Teknik Mal Satu Bentuk Persegi dan Empat Bentuk Belah Lingkaran (Hasanah, 2020)

Dalam hasil penelitian, karya tersebut menghasilkan beberapa motif yaitu, roda bunga 2 motif, dan bunga
Gorga : Jurnal Seni Rupa

Volume 09 Nomor 02 Juli-Desember 2020

p-ISSN: 2301-5942 | e-ISSN: 2580-2380

cinai ada 1 motif. Dan dalam karya tersebut menggunakan dua warna warna kuning dan warna hijau.Warna hijau diterapkan sebagai das ar atau latar belakang sedangkan warna kuning diterapkan dibagian pada motif. Hasil dari pembuatan ornamen oleh siswa terlihat maasih ada kelemahan yaitu bentuk ornamen roda bunga belum menunjukan kerapian serta masih terlihat berantakan dan ornamen bunga cina belum menunjukan kerapian pada sisi tengah, belum sesuai kerapian proporsi pada ornamen ters ebut warna juga belum menunjukan keseluruhan bagian ornamen, cat yang terdapat masih juga tebal tipis, belummenunjukan keserasian pada bidang.

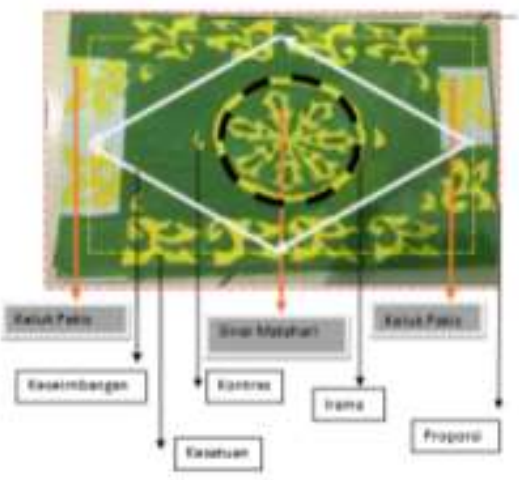

Gambar 8. Ornamen Melayu dengan Teknik Mal Satu Bentuk Lingkaran Berada dalam Belah Ketupat (Hasanah, 2020)

Dalam hasil penelitian, karya tersebut menghasilkan beberapa motif yaitu, keluk pakis ada 2 motif, dan sinar matahari ada 1 motif. Dan dalam karya tersebut menggunakan dua warna warna kuning dan warna hijau.Warna hijau diterapkan sebagai das ar atau latar belakang sedan gkan warna kuning diterapkan dibagian pada motif. Hasil dari pembuatan ornamen oleh siswa terlihat masih ada kelemahan yaitu bentuk ornamen keluk pakis belum menunjukan kerapian serta masih terlihat berantakan dan ornamen sinar matahari juga belummenunjukan kerapian pada sisi lingkaran, wama pada kes eluruhan ornamen juga belum rapi, cat yang terdapat masih tebal tipis, belummenunjukan kerapian pada warna. 

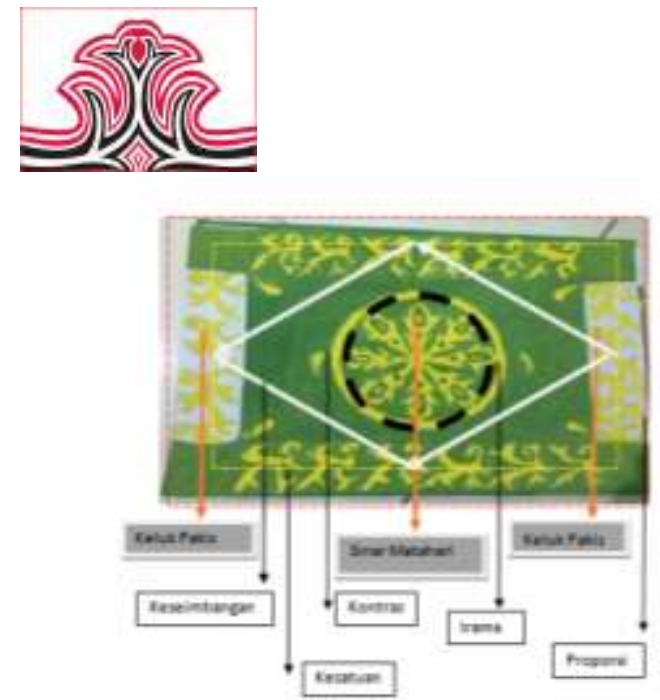

Gambar 9. Ornamen Melayu dengan Teknik Mal Satu Bentuk Lingkaran Berada dalam Belah Ketupat (Hasanah, 2020)

Dalam hasil penelitian, karya tersebut menghasilkan beberapa motif yaitu, keluk pakis ada 2 motif, dan sinar matahari ada 1 motif. Dan dalam karya tersebut menggunakan dua warna warna kuning dan warna hijau.Warna hijau diterapkan sebagai das ar atau latar belakang sedangkan warna kuning diterapkan dibagian pada motif. Hasil dari pembuatan ornamen oleh siswa terlihat maasih ada kelemahan yaitu bentuk ornamen keluk pakis belum menunjukan kerapian serta masih terlihat berantakan dan ornamen sinar matahari juga belummenunjukan kerapian padasisi lingkaran, wama pada keseluruhan ornamen juga belum rapi, cat yang terdapat masih tebal tipis, belummenunjukan kerapian pada warna.

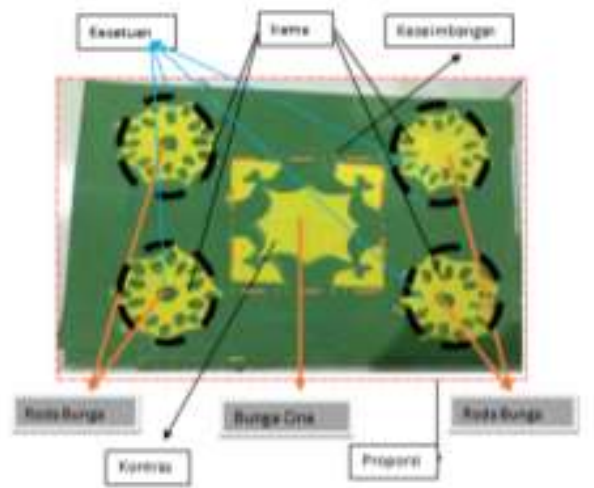

Gambar 10. Ornamen Melayu dengan Teknik Mal Satu Bentuk Persegi dan Empat Bentuk Belah Lingkaran (Hasanah, 2020)

Dalam hasil penelitian, karya tersebut menghasilkan beberapa motif yaitu, roda cina 2 motif, dan bunga cina 1 motif. Dan dalam karya tersebut menggunakan dua warna warna kuning dan warna hijau.Warna hijau diterapkan sebagai dasar atau latar belakang sedangkan warna kuning diterapkan dibagian pada motif. Hasil dari pembuatan ornamen oleh sis waterlihat maasih ada kelemahan yaitu bentuk ornamen roda bunga belum
Gorga : Jurnal Seni Rupa

Volume 09 Nomor 02 Juli-Desember 2020

p-ISSN: 2301-5942 | e-ISSN: 2580-2380

menunjukan kerapian serta masih terlihat berantakan dan ornamen bunga cina belum menunjukan kerapian pada sisi tengah, belum sesuai kerapian proporsi pada ornamen tersebut warna jug a belum menunjukan keseluruhan bagian ornamen, cat yang terdapat masih juga tebal tipis, belum menunjukan keserasian pada bidang.

\section{Pembahasan}

Pembahas an dari hasil karya masing-masing sis wa di atas dapat disimpulkan bahwa berdasarkan penilaian prinsip-prinsip seni rupa pada karya pertama kingga terakhir, maka rata-rata nilai y ang didapat pada prinsip keseimbangan, kesatuan, dan irama memiliki nilai y ang rendah.

Selanjutnya, berdasarkan penilaian prinsip-prin sip seni rupa pada karya masing-masing siswa terdapat nilai yang terendah dengan kategori cukup, terletak pada aspek penilaian kesatuan dan proporsi. Hal ini disebabkan dari ketidaktahuan para sis wa mengenai pentingnya kedua aspek tersebut dalam membuat sebuah karya ornamen Melayu. Adapun pembahasan lebih rinci mengenai prinsip-prinsip seni rupa adalah sebagai berikut. Keseimbangan yang diterapkan pada bidang kertas tidak terdapat pada karya dua dimensi prinsip keseimbangan ditekankan pada bobot kualitatif atau bobot visual. Keseimbangan pada ornamen iniada pada bentuk simetris di mana lingkaran bertumpu pada satu titik pusat saja, keseimbangan yang lain yaitu adanya ornamen pada ujung tepi dari pus at lingkaran. Kesatuan yang muncul pada hasil karya menggambar ornamen Melayu masih belum terlihat menyatu dalam penerapan bentuk dengan pola ragam hias. Secara keseluruhan pada aspek kesatuan karya siswa memperoleh nilai yang relatif cukup.

Irama yang dimunculkan pada hasil karya sis wa masih terdapat pengulangan-pengulangan pola-pola yang terdapat pada gambar masih terlihat belum rapi, susunannya pola-pola belum menarik dari gambar di atas pengulangan pada pola- pola belum menunjukan kerapian yang teratur masih kurang rapi dan masih terlihat kas ar. Proporsi dari rata-rata keseluruhan karya ornamen Melayu siswa masih terdapat pada gambar belum menciptakan keteraturan dan jarak yang baik, cenderung masih terlihat berantakan.

\section{KESIMPULAN DAN SARAN 1.Kesimpulan}

Berdasarkan hasil penelitian tersebut, maka peneliti menyimpulkan bahwa secara keseluruhan hasil karya ornamen Melayu siswa SMA Negeri 1 Talawi termasuk ke dalam kategori cukup dengan nilai yang relatif rendah. Penerapan teknik patron/mal terhadap hasil 


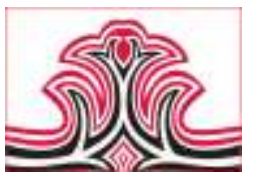

karya ornamen Melayu juga membuahkan hasil yang lebih signifikan dibandingkan menggunakan teknik lama. Adapun kesimpulan-kesimpulan berdasarkan prinsip-prinsip seni rupa yaitu sebagai berikut: Kesatuan yang muncul pada hasil karya menggambar ornamen Melayu masih belum terlihat menyatu dalam penerapan bentuk dengan pola ragam hias. Secara keseluruhan pada aspek kesatuan karya siswa memperoleh nilai yang relatif cukup. Irama yang dimunculkan pada hasil karya siswa masih terdapat pengulangan-pengulangan pola-pola yang terdapat pada gambar masih terlihat belum rapi, susunannya pola-pola belum menarik dari gambar di atas pengulangan pada pola- pola belum menunjukan kerapian yang teratur masih kurang rapi dan masih terlihat kasar. Proporsi dari rata-rata kes eluruhan karya ornamen Melayu siswa masih terdapat pada gambar belum menciptakan keteraturan dan jarak yang baik, cenderung masih terlihat berantakan.

\section{Saran}

Berdasarkan hasil penelitian dan kesimpulan dari penelitian ini, maka peneliti menyampaikan beberapa saran berikut ini: 1). Disarankan sis wa lebih dahulu mengamati bentuk dan jenis ragam hias sebelum membuat sketsa, 2). Disarankan siswa mampu membuat variasi warna seperti, hijau tua, hijau muda, kuning tua, dan kuning muda., 3). Dis arankan siswa mampu membuat varias i pengulangan bentuk yaitu ada bentuk keci, sedang dan besar, dan 4). Disarankan kepada guru mampu memberikan contoh dan mempraktikan tahapan menggambar ragam hias ornamen Melayu.

\section{DAFTAR RUJUKAN}

Hasanah, U. (2020). "Kumpulan Karya Batik dengan Teknik Mal". Hasil Dokumentasi Pribasi: 17 Mei 2020, SMA Negeri 1 Talawi.

Moussavi. F and Kubo, M. (2010) The Function of Ornament. Harvard University School of Design.

Pratiwi, Djati. (2001). Pola Dasar dan Pecah Pola

Busana. Jakarta: Kanisius.

Sahman, Humar. (1993). Mengenali Dunia Seni Rupa, Tentang Seni, Karya Seni, Aktivitas Kreatif, Apresiasi, Kritik dan Estetika, Semarang: IKIP Semarang Press

Sembiring, Dermawan. (2013) Wawasan Seni. Medan: Unimed Press

Siregar, N. H., Azis, A.C. K., Mesra, M., \& Mirwa, T. (2020). Analisis Gambar Bentuk Bunga Anggrek dengan Teknik Pointilis Berwarna di SMP Al-Fityan School Medan. Gorga: Jurnal Seni Rupa, 9(1), 94-99. 